\title{
Diversity of Culturable Halophilic Archaea and Bacteria from Chott Tinsilt and El Malah Salt-Lake in Algeria
}

\author{
${ }^{1}$ Akmoussi-Toumi Siham, ${ }^{2}$ Khemili-Talbi Souad, ${ }^{1}$ Kebbouche-Gana Salima, \\ ${ }^{3}$ Lenchi-Izouine Nesrine, ${ }^{1}$ Khelfaoui Mohamed Amine, ${ }^{1}$ Sayah Amna, \\ ${ }^{1}$ Bouarab Ghania, ${ }^{3}$ Ferrioune Imen, ${ }^{1}$ Mokhtari Wafa and ${ }^{4}$ Najjari Afef \\ ${ }^{1}$ Laboratoire VALCORE, Faculté des Sciences, \\ Université M'Hamed Bougara, Avenu de l'indépendance Boumerdes 35000, Algeria \\ ${ }^{2}$ Département de Biologie, Faculté des Sciences, \\ Université M'Hamed Bougara, Avenu de l'indépendance Boumerdes 35000, Algeria \\ ${ }^{3}$ Département Sciences de la Nature et de la vie, \\ Faculté des Sciences, Université Benyoucef Benkheda (Alger 1) 2 Rue Didouche Mourad, Alger, Algérie \\ ${ }^{4}$ Faculté des Sciences de Tunis, Université de Tunis El Manar, \\ LRO3ES03 Microorganismes et Biomolécules Actives, 2092, Tunis, Tunisia
}

Article history

Received: 25-12-2019

Revised: 13-01-2020

Accepted: 24-02-2020

Corresponding Author:

Akmoussi-Toumi Siham

Laboratoire VALCORE,

Faculté des Sciences,

Université M'Hamed Bougara

Avenu de l'indépendance

Boumerdes 35000, Algeria

Email: s.akmoussi@univ-boumerdes.dz

\begin{abstract}
At the limits of life, hyper-saline aquatic ecosystems; Chott and Sebkha are a model of choice of extreme environments, housing a halophilic microflora that had to adapt to these conditions. In Algeria, these ecosystems are poorly studied. However, our study was carried out on the waters of Chott Tinsilt and Sebkha El Malah. The study of this microflora revealed the presence of a significant morphological, physiological and metabolic diversity. The molecular study allowed us to access to a phylogenetic affiliation including an Archean Species (ATS1) and 7 bacterial species (A1, A2, A3, A4, B1, B4, B5). The results showed that these isolates were related to the genera Haloferax (for the strain ATS1) and Halomonas (strains A1, A2 and A4), Staphylococcus (strain A3), Salinivibrio (strain B1), Planococcus (strain B4) and Halobacillus (strain B5). Most isolates produced hydrolases at high salt concentrations. The Production yields obtained are very promising for applications in the biotechnology and industrial microbiology.
\end{abstract}

Keywords: Chott, Halophiles, 16S rRNA, Phylogenic Analysis, MEGA6.06

\section{Introduction}

Saline and hypersaline environments constitute the largest ecosystems on the planet (Ghosh et al., 2019). During recent years, the microbial diversity of such environments has been widely explored (Borsodi et al., 2013). Halophiles can be found in a wide range of hypersaline environments that are widely distributed in various geographic areas of the earth, such as marine salterns, salt lakes and saline soils (Amoozegar et al., 2019).

These microorganisms can be found in the three domains of life, whose Archaea, Bacteria and Eukarya are distinguished by their requirement of salinity conditions for growth (Amoozegar et al., 2019). They may be classified into three main classes according to the quantity of their salt $(\mathrm{NaCl})$ requirements: slight halophiles which require 0.2 to $0.85 \mathrm{M}$, Moderate halophiles, which require 0.85 to $3.4 \mathrm{M}$ and extreme halphiles, which need 3.4 to $5.1 \mathrm{M}$ of $\mathrm{NaCl}$. Halotolerant microorganisms are those that can grow in the presence and absence of high concentrations of salt (Singh et al., 2019).

Due to their ability to adapt in hostile conditions, halophiles present specific characteristics, with biotechnological and industrial interests such as, the capacity to produce hydrolytic enzymes with stable and optimal activities under harsh conditions of temperature, salt concentration and $\mathrm{pH}$; an extreme state which leads to the denaturation and aggregation of most proteins (DasSarma and DasSarma, 2015).

Many halophiles are capable of secreting extracellular hydrolytic enzymes such as amylases, cellulases, xylanases, proteases and lipases (Govender et al., 2009; Enache and Kamekura, 2010; Delgado-García et al., 2015). These enzymes are able to catalyze the hydrolytic reactions under high salt concentrations and they are called halophilic hydrolases (Delgado-García et al., 2012; Liu et al., 2019).

Halophiles form a group of extremophiles relatively few explored compared to thermophiles, alkalophiles and 
acidophiles, although they have been used traditionally for the production of salt and even for the preservation of foodstuffs, few products derived from halophiles (for example, beta-carotene from Dunaliella and ectoine from moderately halophilic bacteria) have been able to enter the world market (Oren, 2010). However, no haloarchean enzyme has reached the level of production and commercial distribution to date (Das et al., 2019).

In addition, Algeria has several wetlands and hypersaline lakes, with a specific typology and ecology, of which 50 are classified as sites of international importance as Ramsar sites (Aliat et al., 2016). However, all aspects related to the microbiota composition (diversity and bioactivity) are few studied and remain unidentified (Hacene et al., 2004; Kebbouche-Gana et al., 2009; Boutaiba et al., 2011; Kharroub et al., 2014; Quadri et al., 2016; Menasria et al., 2018; 2019).

In this report, we tried to discuss the diversity of the halophilic bacterial communities living in two Sebkha located in the semi-arid zones of north-eastern Algeria by describing their phenotypic characteristics and phylogenetic affiliation, as well as their potential production of hydrolytic enzymes and their applications in various biotechnological processes.

\section{Materials and Methods}

\section{Sampling, Isolation and Cultivation of Halophilic Bacteria and Archaea}

Water samples from two sites (chotts and sebkha) located in the Hauts Plateaux of Northeastern Algeria, were collected aseptically in sterile plastic bottles and were directly cultivated. The samples were collected from Chott Tinsilt (Biskra) and Sebkha EL Malah (Medea) in the northeastern of the Algerian Sahara.

In order to isolate halophilic archaeal and bacterial strains, $10 \mathrm{~mL}$ of diluted water sample was added in 100 $\mathrm{mL}$ of the modified Standard Halophilic $(\mathrm{SH})$ medium (Oren et al., 1995) containing (in g/L): $\mathrm{MgCl}_{2} \cdot 6 \mathrm{H}_{2} \mathrm{O}, 20$; $\mathrm{K}_{2} \mathrm{SO}_{4}, 5 ; \mathrm{CaCl}_{2}, 0.1$; yeast extract (Difco), 1 ; starch, 2 and supplemented with different total salt concentrations (5-30\%). The $\mathrm{pH}$ was adjusted to 7.2 before autoclaving. For solid medium, $20 \mathrm{~g} / \mathrm{L}$ Bacto-agar (Difco) was added. The plates were incubated for $7-15$ days at $40^{\circ} \mathrm{C}$. After six weeks of incubation, pure cultures were obtained and stored on solid $\mathrm{SH}$ medium with appropriate total salt concentration at $4^{\circ} \mathrm{C}$.

\section{Phenotypic Characterization of the Isolated Strains}

Colony morphology was observed under optimal growth conditions on solid $\mathrm{SH}$ medium after incubation at $40^{\circ} \mathrm{C}$ for 7 days. Gram staining of cells was performed as described by Dussault (1955) for Archean isolates and by the Burke method (Murray et al., 1994) for bacterial isolates. Growth and optimal conditions were determined at different temperatures $(4,25,30,37,40,55$ and $\left.60^{\circ} \mathrm{C}\right), \mathrm{pH}(4.0,5.0,6.0,8.0,9,0,10.0$ and 12.0) and in various salt concentrations (0-30\%) on $\mathrm{SH}$ agar for 7-15 days of incubation. The growth was carried out by spreading $0.2 \mathrm{~mL}$ of a culture suspension of each strain on the surface of the respective media.

\section{Molecular Identification by $16 S$ rRNA Sequencing and Phylogenetic Analysis}

\section{Genomic DNA Extraction and PCR Amplification}

Extraction of genomic DNA from the isolated strains is carried out during their exponential growth phase using a Wizard genomic DNA purification kit (Promega, Madison, WI, USA) according to the manufacturer's protocol. The 16S rRNA gene was amplified with the bacterial primers pair Fd1 (5'-AGA-GTT-TGA-TCCTGG-CTC-AG-3') and Rd1 (5'-AAG -GAG-GTG-ATCCAG-CC-3') (Aguilera et al., 2009) and archaeal primers pair 21F (5'-TTCCGGTTGA TCCTGCCGGA-3') and 1492R

(5'-GGTTACCTTGTTACGACTT-3') (Kebbouche-Gana et al., 2009). The PCR mixture is composed of $0.5 \mu \mathrm{L}$ of each primer $(50 \mathrm{mM}) ; 10 \mu \mathrm{L}$ of Biogenic LOADTM Taq polymerase (1X); $0.5 \mu \mathrm{L}$ of template DNA. The mixture is completed with $38.5 \mu \mathrm{L}$ of sterile water. The Taq used is a ready prepared PCR reaction mixture containing the following components: Taq polymerase, dNTP, PCR buffer, $\mathrm{MgCl} 2$ and deposition buffer. PCR amplification consisted of an initial denaturation at $94^{\circ} \mathrm{C}$ for $5 \mathrm{~min}$, followed by 30 denaturation cycles at $94^{\circ} \mathrm{C}$ for $30 \mathrm{~s}$, annealing at $52^{\circ} \mathrm{C}$ for $45 \mathrm{~s}$, extension at $72^{\circ} \mathrm{C}$ for $2 \mathrm{~min}$ and a final polymerization step of $72^{\circ} \mathrm{C}$ for $10 \mathrm{~min}$.

\section{Sequencing and Phylogenetic Analysis}

PCR products were determined and sequencing was performed by using the automated DNA sequencer ABI PRISM ${ }^{\circledR}$ 3100-Avant Genetic Analyser (Applied Biosystems, Foster City, CA, USA). The obtained sequence was compared with sequences available in the public sequence databases using the BLAST search program (http://www.ncbi.nlm.nih.gov). The multiple sequence alignment was performed by means of the ClustalW program. Phylogenetic and molecular evolutionary genetic analyses were performed using the Molecular Evolutionary Genetics Analysis (MEGA) software version 6.06 (Tamura et al., 2013). Evolutionary distance matrix was generated and phylogenetic tree was constructed using the neighbor-joining method. The topologies were evaluated by bootstrap sampling expressed as percentage of 1000 replicates. 


\section{Screening of Hydrolytic Exo-Enzymes}

To get a qualitative detection of producing extracellular hydrolyses, different enzymatic agar plate assays were performed using a drop spot technique. The standard methods referenced for each enzyme were modified to make suitable condition for growth which corresponds to each isolate as described for amylase (Montalvo-Rodriguez et al., 1998), gelatinase (Frazier, 1926), esterase (Sierra, 1957), lipase (Kouker and Jaeger, 1987), cellulase (Teather and Wood, 1982), protease (Gonzalez et al., 1978), xylanase (Ghio et al., 2012), chitinase (Roberts and Selitrennikoff, 1988) and tannase (Aissam, 2003). After incubation of each isolate for 3 to 10 days, the results were expressed qualitatively as Levels of Enzymatic Activities (LEA) (High activity, medium activity, low activity and no activity) (Latorre et al., 2016) using the formula LEA = diameter of the zone of clearance/the diameter of colony in millimeters.

\section{Results and Discussion}

\section{Isolation and Phylogenetic Characterization of the Halophilic Isolates}

In recent years, halophilic prokaryotes have been widely explored and have been found in a wide range of saline environments. For their biotechnological applications, extreme and moderate halophilic bacteria have received high attention (Edbeib et al., 2016; Margesin and Schinner 2001; Oren, 2002). However, culture-based methods remain an essential approach to obtaining new microbes that offer application of new potentials and an understanding of their ecophysiological and environmental functions (Menasria et al., 2018). Throughout this work, we have characterized seven moderate halophiles and one extreme halophilic isolate. The isolates were named (ATS1, A1, A2, A3, A4, B1, $\mathrm{B} 4$ and B5). The color of colonies ranged from pale-pink to red-orange. The cells were Gram-negative polymorphic, short rods or coccus. All stained Gram negative and were catalase- and oxidase positive.

All the isolates were halophilic, had a salt concentration for growth at least $5 \%(\mathrm{w} / \mathrm{v}) \mathrm{NaCl}$ and could tolerate salt concentration up to $20-25 \%$ (w/v) $\mathrm{NaCl}$. The isolates grew best between 30 and $45^{\circ} \mathrm{C}$ and $\mathrm{pH}$ of 6 to 8, with the exception of some isolates showed a growth at $50^{\circ} \mathrm{C}$ and $\mathrm{pH}$ up to 9 . Overall, the isolates showing a large range of growth temperature extend from $25^{\circ} \mathrm{C}$ to $50^{\circ} \mathrm{C}$ (Fig. 1). The microbial community of hypersaline environments is dominated by well-adapted halophilic microorganisms which in many cases are polyextremophiles with the ability to grow optimally not only at high salt concentrations but also at high or low $\mathrm{pH}$ values and temperatures (Bowers et al., 2009; Mesbah and Wiegel, 2012).
Sequencing of the 16S rRNA genes and phylogenetic analysis of the 8 selected strains allowed the identification of 6 genera: Haloferax, Halomonas, Staphylococcus, Salinivibrio, Halobacillus and Planococcus (Fig. 2 and Table 1). The isolates revealed high degree of similarity, with the closest described species in terms of colony, cells morphologies and physiological characteristics.

The results presented in Table 1 indicate the description of six different genera with the dominance of Halomonas (3 strains) followed by Halobacillus (2 strains) and Staphylococcus, Salinivibrio, Planococcus, Haloferax (1 strain each). Haloferax specie was isolated from Sebkha Al Malah. The strain ATS1 has been identified as a member of the family Halobacteriaceae. The complete 16S rRNA gene sequence of the strain ATS1 was 1490 bp (Genbank accession number: MF353936) and showed 98\% significant sequence similarity to that of the Haloferax mediterranei strain ATCC 33500T. This species was found in Sebkha Ezzemoul (Ain M'Lila) (Kharroub, 2007), Sidi Ameur (Bousaâda) (Quadri et al., 2016) as well as in Sebkha Medghacen and Sebkha El Hamiet (Menasria et al., 2018).

Three strains (A1, A2 and A4) were found to be phylogenetically attached to members of the genus Halomonas with at least $96 \%$ similarity. These strains were isolated from different sites: Chott El Beïdha, Chott Tinsilt, Chott Kralla, Sebkha Djendli, Sebkha El Hamiet, Sebkha Medghacen and Sebkha Oumache in Algerian Saline Ecosystems (Sebkha and Chott) located in arid and semi-arid ecoclimate zones (Northeastern Algeria) (Menasria et al., 2019).

Whereas, the sequence of the A3 strain showed a low level of homology with those of reference strains close to the genus Staphylococcus arlettae strain $3 \mathrm{~m}-3$ (JX188021) with 95\% homology. This test alone can justify the classification of this strain in a new species. The 16S sequence of the rDNA of the B1 strain has $96 \%$ homology to that of Salinivibrio costicola strain cepa 6 (X95531) and 94\% to that of Salinivibrio proteolyticus strain M1SED9 (JX501730) (Table 1). These are halophilic bacteria commonly found in hypersaline aquatic habitats and in salty foods. This genus includes five species and two subspecies (Galisteo et al., 2019).

While the strain B3 and B5 were 99 and 98\% homology respectively, to that of Halobacillus karajensis isolate HK-03 (HG931925), Halobacillus dabanensis isolate HD-02 (HG931924) and Halobacillus trueperi isolate HT-01 (HG931926). These species had also been isolated from saline soil (Iran) (Amoozegar et al., 2003), salt lakes in Xinjiang, China (Liu et al., 2005) and the Great Salt Lake Utah (USA) (Spring et al., 1996).

The strain B4 is affiliated to the species Planococcus rifietoensis strain SAL-15 (HE573181) and Planococcus 
citreus strain NBRC 15849 (NR_113814) with a homology of $96 \%$. This species has also been isolated from saline soils in Pakistan (Rajput et al., 2013) and salt ponds in Korea (Yoon et al., 2010).

\section{Screening for Halophilic-Active Hydrolytic Enzymes}

The enzymatic production of halophilic microorganisms is poorly exploited commercially. One of the advantages of these enzymes is its ability to catalyze reactions under extreme conditions, mainly at high salt concentrations, but also at high or low $\mathrm{pH}$ values and temperatures (Enache and Kamekura 2010; Mesbah and Wiegel, 2012). These properties allow them to be used in industrial processes using rigorous physico-chemical conditions (Setati, 2009; Oren, 2010). These enzymes are called halozymes, enzymes that exhibit tolerant or salt-dependent catalytic activity (Gupta et al., 2016).

Table 1: Phylogenetic affiliation of the bacterial and Archean strains studied

\begin{tabular}{|c|c|c|c|c|}
\hline Isolates & Genus & Related species & Similarity $\%$ & Accession number \\
\hline \multirow[t]{4}{*}{$\overline{\mathrm{Al}}$} & Halomonas & Halomonas venusta & 96 & AY553074 \\
\hline & & Halomonas janggokensis & 96 & NR_04248 \\
\hline & & Halomonas variabilis & 96 & AM945682 \\
\hline & & Halomonas subterranean & 96 & NR_04411 \\
\hline \multirow[t]{3}{*}{$\mathrm{A} 2$} & Halomonas & Halomonas venusta & 97 & AY553074 \\
\hline & & Halomonas variabilis & 97 & AY505527 \\
\hline & & Halomonas janggokensis & 97 & KM488473 \\
\hline A3 & Staphylococc & Staphylococc arlettae & 95 & JX188021 \\
\hline \multirow[t]{2}{*}{ A4 } & Halomonas & Halomonas aquamarina & 97 & EU624431 \\
\hline & & Halomonas venusta & 96 & KF933652 \\
\hline \multirow[t]{2}{*}{ B1 } & Salinivbrio & Salinivbrio costicola & 96 & X95531 \\
\hline & & Salinivibrio proteolyticus & 94 & JX501730 \\
\hline \multirow[t]{3}{*}{ B3 } & Halobacillus & Halobacillus karajensis & 99 & HG931925 \\
\hline & & Halobacillus dabanensis & 99 & HG931924 \\
\hline & & Halobacillus trueperi & 99 & HG931926 \\
\hline \multirow[t]{2}{*}{ B4 } & Planococcus & Planococcus rifietoensis & 96 & HE573181 \\
\hline & & Planococcus citreus & 96 & NR_11381 \\
\hline \multirow[t]{3}{*}{ B5 } & Halobacillus & Halobacillus karajensis & 98 & HG931925 \\
\hline & & Halobacillus dabanensis & 98 & HG931924 \\
\hline & & Halobacillus trueperi & 98 & HG931926 \\
\hline ATS1 & Haloferax & Haloferax mediterranei & 98 & MF353936 \\
\hline
\end{tabular}

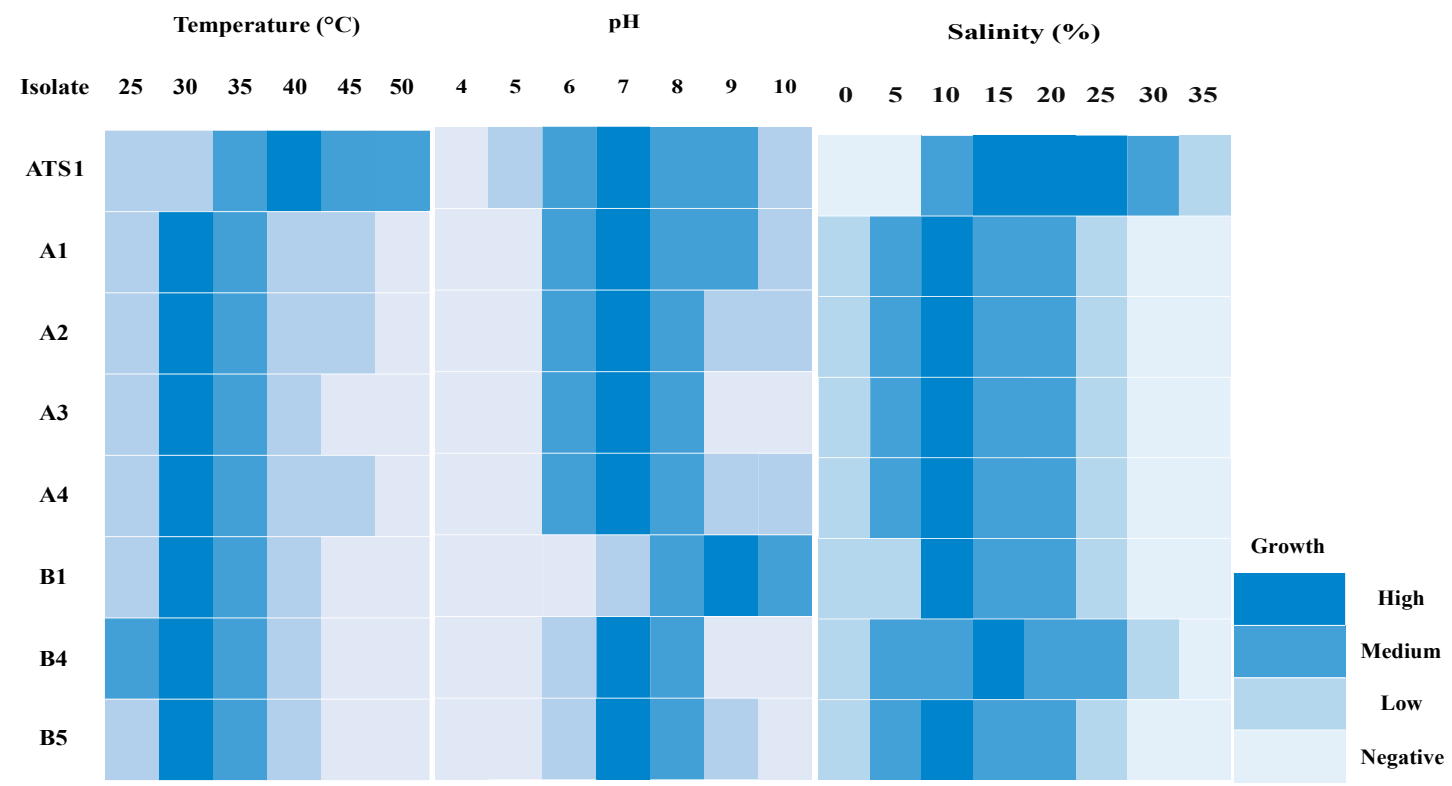

Fig. 1: Heat map plots of physiological features of halophilic isolates 


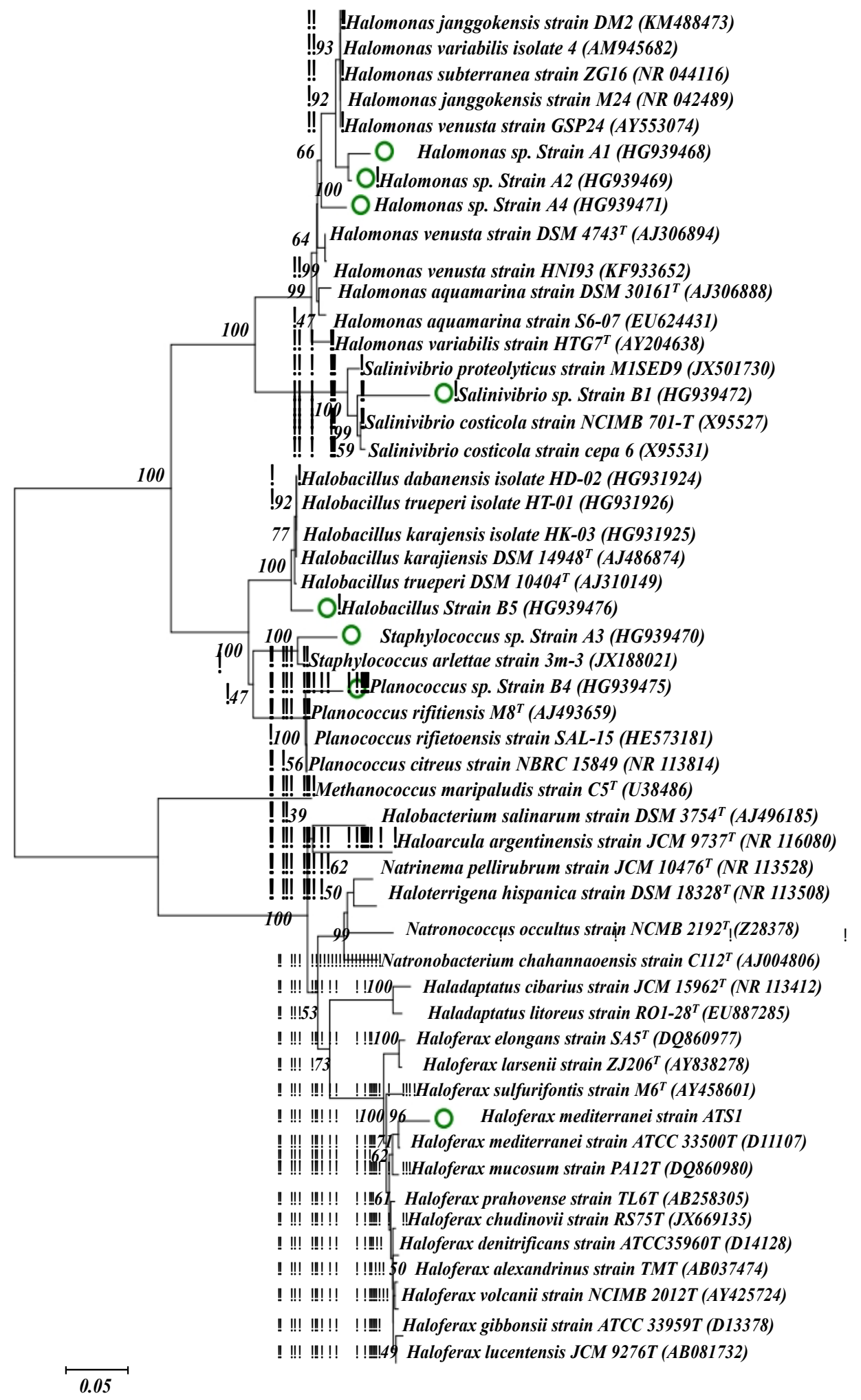

Fig. 2: Dendrogram indicating the position of strains A1, A2, A3, A4, B1, B4, B5 and ATS1 (green circle) based on their 16S rDNA sequences by MEGA6.06 software. The numbers above the branches refer to bootstrap values. Methanococcus maripaludis strain C5T (U38486) was used as the out group. The scale bar indicates a substitution of 5 nucleotides for each 10 nucleotides sequence. The sequence access numbers publicly available in Genbank are shown in parentheses. 
All the eight isolates were tested for extracellular hydrolase producing activity by plate assay on starch, Carboxymethylcellulose (CMC), tween, olive oil, skim milk, xylane, tannic acid, colloidal chitin and gelatin agar plates for Amylase (Amy), Cellulose (CMC), Esterase (Est), Lipase (Lip), Protease (Prot), Xylanase (Xyl), Tannase (Tan), Chitinase (Chit) and Gelatinase (Gel) respectively.

Screening for extracellular halophilic enzymes showed that the majority of isolates produced at least four hydrolytic enzymes, respectively (Fig. 3). Lipases, esterases, amylases and proteases constitute the most abundant enzymes (produced in the majority of isolated halophilic strains). Followed by gelatinase and tannase in terms of activity. Many isolates showed several hydrolytic activities combined, mainly strain ATS1 affiliated to Haloferax mediterranei.

Sánchez-Porro et al. (2003) showed the abundance of five hydrolases including amylase, protease, lipase, DNase and pullulanase in a moderate halophilic community isolated from water and Spanish saline sediments, with an abundance of activity amylolytic. Though, Moreno et al. (2009) studied the diversity of extreme halophiles producing lipases, proteases, amylases and nucleases in crystallization ponds located in Southern Spain, at a rate of $70 \%$ of the total of isolates, while no DNAase activity has been detected. In a similar study, Cojoc et al. (2009) have elucidated the extracellular hydrolytic activities of halophilic bacteria, with lipolytic and proteolytic activities predominant for the isolated strains.

The same results were obtained by Makhdoumi Kakhki et al. (2011) reporting the capacity of halophilic archaea from hypersaline lake Aran-Bidgol (central desert region in Iran), to produce different types of hydrolases, concluding that Halorubrum and Haloarcula were the most dominant Haloarchean genera with a high enzyme production rate comprising amylase respectively, DNase and lipase. However, Kharroub et al. (2014) report the capacity of halophilic archaea from Algerian Sebkha to produce amylolytic enzymes with a high prevalence. Furthermore, Gupta et al. (2016) found that the five bacterial isolates halophilic produce one or more haloenzymes such as amylase, protease, lipase and glutaminase.

Menasria et al. (2019) report that the enzymes amylase, esterase, gelatinase and nuclease activities are classified first in the group of hydrolases. While Menasria et al. (2018), report that the esterase and inulinase activities have the highest activities. Probably because biotopes represent an important reservoir of organic matter which can stimulate the metabolic activity of isolated halophilic archaea. The results of this present work as well as those of Boutaiba et al. (2006) also demonstrate that Archean halophilic isolates can produce lipase with a high concentration of $\mathrm{NaCl}$.

According to these results, a great diversity was displayed concerning their biotechnological aptitudes to produce metabolites of interest, particularly the ATS1 strain which displayed the best potential for the production of lipase, protease and tannase among all the halophilic strains studied. The results obtained confirm the great capacity of the isolated strains to synthesize enzymatic activities. These biomolecules are essential metabolites that allow bacteria to catabolize nutrients in the environment to ensure their lives. In addition, these natural capacities are used for the benefit of biotechnology in various fields (Zhao et al., 2010).

Enzyme production

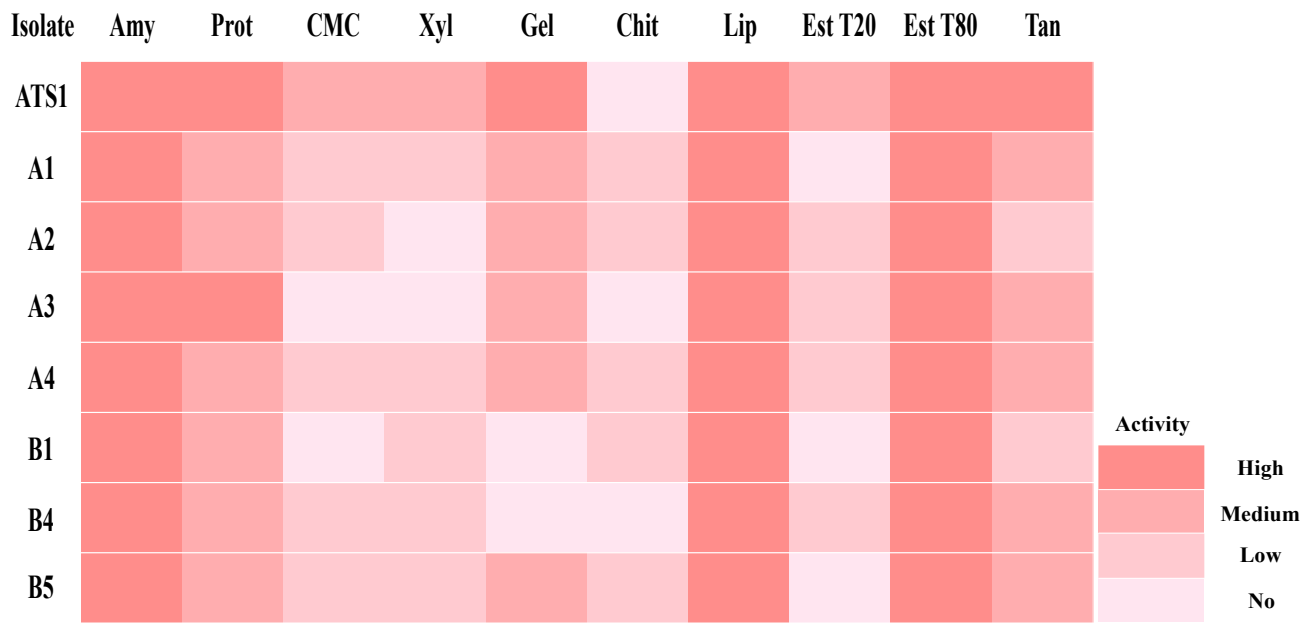

Fig. 3: Heat map plots of enzymatic activities of halophilic isolates 


\section{Conclusion}

This work studies the biodiversity of halophilic isolates from the Algerian Saline wetlands. The data have shown that different sebkha ecosystems of Tinsilt and Al Malah are good sources of isolation of extreme and moderate halophiles by the culture dependent approach producing extracellular hydrolytic enzymes of biotechnological importance. However, further studies are necessary to better understand the microbial ecology, their distribution and their functional diversity in such hypersaline environments.

\section{Acknowledgement}

This work was supported by the PRFU project finaced by the "Direction Générale de la Recherche Scientifique et du développement technologique (DGRSDT)" of Algerian Ministry of Higher Education and Scientific Research.

The authors thank Professor Khemili Amina for her careful reading and advancing.

\section{Author's Contributions}

Akmoussi-Toumi Siham, Khemili-Talbi Souad, Kebbouche-Gana Salima, Najjari Afef: Conceived and designed the study, provided supervision of analyzed data and wrote the paper.

Akmoussi-Toumi Siham, Lenchi-Izouine Nesrine, Khelfaoui Mohamed Amine and Mokhtari Wafa: Performed experiments and Analyzed data.

Sayah Amna, Bouarab Ghania, Ferrioune Imen: Contributed reagents/materials/analysis tools.

\section{Ethics}

This article is original and contains unpublished material. The corresponding author confirms that all of the other authors have read and approved the manuscript and no ethical issues involved.

\section{References}

Aguilera, M., M.L. Jiménez-Pranteda, K. Kharroub, A. González-Paredes and J.J. Durban et al., 2009. Marinobacter Lacisalsi sp. Nov., a moderately halophilic bacterium isolated from the saline-wetland wildfowl reserve Fuente de piedra in Southern Spain. Int. J. Systemat. Evolut. Microbiol., 59: 1691-1695. DOI: 10.1099/ijs.0.007518-0

Aissam, H., 2003. Etude de la biodegradation des effluents des huileries (Margines) et leur valorisation par production de l'enzyme tannase. $\mathrm{PhD}$ Thesis, Sidi Mohamed Ben Abdellah University, Morocco.
Aliat, T., M. Kaabeche, H. Khomri, L. Nouri and S. Neffar et al., 2016. A pedological characterisation of some inland wetlands and ramsar sites in Algeria. Land Degradat. Dev., 27: 693-705.

DOI: 10.1002/LDR.2467

Amoozegar, M.A., A. Safarpour, K.A. Noghabi, T. Bakhtiary and A. Ventosa, 2019. Halophiles and their vast potential in biofuel production. Frontiers Microbiol., 10: 1895-1895.

DOI: $10.3389 /$ fmicb.2019.01895

Amoozegar, M.A., F. Malekzadeh and K.A. Malik, 2003. Production of amylase by newly isolated moderate halophile, Halobacillus sp. Strain MA-2. Microbiol. Meth., 52: 353-359. DOI: 10.1016/s0167-7012(02)00191-4

Borsodi, A.K., T. Felfoldi, I. Mathe, V. Bognar and M. Knab et al., 2013. Phylogenetic diversity of bacterial and archaeal communitie inhabiting the saline lake red located in sovata, Romania. Extremophiles, 17: 87-98. DOI: 10.1007/S00792-012-0496-2

Boutaiba, S., H. Hacene, K.A. Bidle and J.A. MaupinFurlow, 2011. Microbial diversity of the hypersaline sidi ameur and himalatt salt lakes of the Algerian Sahara. Arid Environ., 75: 909-916.

DOI: $10.1016 /$ j.jaridenv.2011.04.010

Bowers, K.J., N. Mesbah and M. Wiegel, 2009. Biodiversity of polyextremophilic bacteria: Does combining the extremes of high salt, alkaline $\mathrm{pH}$ and elevated temperature approach a physicochemical boundary for life. Saline Syst., 5: 9-9. DOI: 10.1186/1746-1448-5-9

Cojoc, R., S. Merciu, G. Popescu, L. Dumitru and M. Kamekura et al., 2009. Extracellular hydrolytic enzymes of halophilic bacteria isolated from a subterranean rock salt crystal. Romanian Biotechnol. Lett., 14: 4658-4664.

Das, D., I. Kalra, K. Mani, B.B. Salgaonkar and J.M. Braganca, 2019. Characterization of extremely halophilic archaeal isolates from Indian salt pans and their screening for production of hydrolytic Enzymes. Environ. Sustainability, 2: 227-239.

DOI: $10.1007 / S 42398-019-00077-X$

DasSarma, S. and P. DasSarma, 2015. Halophiles and their Enzymes: Negativity put to good use. Curr. Opin. Microbiol., 25: 120-126.

DOI: 10.1016/j.mib.2015.05.009

Delgado-García, M., B. Nicolaus, A. Poli, C.N. Aguilar and R. Rodríguez-Herrera, 2015. Isolation and Screening of Halophilic Bacteria for Production of Hydrolytic Enzymes. In: Sustainable Development and Biodiversity, Maheshwari, D. and M. Saraf (Eds.), Springer, Cham,

ISBN-13: 978-3-319-14594-5, pp: 379-401. 
Delgado-García, M., B. Valdivia-Urdiales, C.N. AguilarGonzález, J.C. Contreras-Esquivel and R. RodríguezHerrera, 2012. Halophilic hydrolases as a new tool for the biotechnological industries. J. Sci. Food Agric., 92: 2575-2580. DOI: 10.1002/jsfa.5860

Dussault, H.P., 1955. An improved technique for staining red halophilic bacteria. J. Bacteriol., 70: 484-485.

Edbeib, M.F., A.W. Roswanira and F. Huyop, 2016. Halophiles: Biology, adaptation and their role in decontamination of hypersaline environments. World J. Microbiol. Biotechnol., 32: 135-135. DOI: $10.1007 / \mathrm{s} 11274-016-2081-9$

Enache, M. and M. Kamekura, 2010. Hydrolytic enzymes of halophilic microorganisms and their economic values. Romanian Biotechnol. Lett., 47: 47-59.

Frazier, W.C., 1926. A method for detection of changes in gelatin due to bacteria. J. Inf. Dis., 39: 302-309.

Galisteo, C., C. Sánchez-Porro, R.R. De la Haba, C. López-Hermoso and A.B. Fernández et al., 2019. Characterization of Salinivibrio socompensis sp. nov., A new halophilic bacterium isolated from the high-altitude hypersaline lake socompa, Argentina. Microorganisms, 7: 241-241.

DOI: $10.3390 /$ microorganisms7080241

Ghio, S., G. Sabarís Di Lorenzo, V. Lia, P. Talia and A. Cataldi et al., 2012. Isolation of Paenibacillus sp. and Variovorax sp. Strains from decaying woods and characterization of their potential for cellulose deconstruction. Int. J. Biochem. Molecular Biol., 3: 352-364.

Ghosh, S., S. Kumar and S. Kumar Khare, 2019. Microbial Diversity of Saline Habitats: An Overview of Biotechnological Applications. In: Microorganisms in Saline Environments: Strategies and Functions, Giri, B. and A. Varma (Eds.), Springer, Cham,

ISBN-13: 978-3-030-18975-4, pp: 65-92.

Gonzalez, C., C. Gutierrez and C., Ramirez, 1978. Halobacterium vallismortis sp. nov. An amylolytic and carbohydrate-metabolizing: Extremely halophilic bacterium. Canadian J. Microbiol., 24: 710-715. DOI: 10.1139/m78-119

Govender, L., L. Naidoo and M.E. Setati, 2009. Isolation of hydrolase producing bacteria from sua pan solar salterns and the production of Endo-1, 4- $\beta$-Xylanase from a newly isolated Haloalkaliphilic nesterenkonia sp. African J. Biotechnol., 8: 5458-5466.

Gupta, S., P. Sharma, K. Dev and A. Sourirajan, 2016. Halophilic bacteria of lunsu produce an array of industrially important enzymes with salt tolerant activity. Biochem. Res. Int.

Hacene, H., R. Fatima, C. Nabila, S. Boutaiba and B. Tej et al., 2004. Biodiversity of prokaryotic microflora in el golea salt lake, Algerian Sahara. J. Arid Environ., 58: 273-284.

DOI: $10.1016 /$ j.jaridenv.2003.08.006
Kebbouche-Gana, S., M. Gana, S. Khemili, F. FazouaneNaimi and N. Bouanane et al., 2009. Isolation and characterization of halophilic archaea able to produce biosurfactants. J. Industrial Microbiol. Biotechnol., 36: 727-738. DOI: 10.1007/s10295-009-0545-8

Kharroub, K., 2007. Identification et étude moléculaire des bactéries et des archéobactéries aérobies halophiles de la sebkha ezzemoul (Ain M'Lila). PhD Thesis Mentouri-Constantine University, Algeria.

Kharroub, K., M.A. Gomri, M. Aguilera and M. Monteoliva-Sánchez, 2014. Diversity of hydrolytic enzymes in haloarchaea isolated from algerian sabkhas. African J. Microbiol. Res., 8: 3992-4001. DOI : 10.5897/AJMR2014.7183

Kouker, G. and K.E. Jaeger, 1987. Specific and sensitive plate assay for bacterial lipases. Applied Environ. Microbiol., 53: 211-213

Latorre, J.D., X. Hernandez-Velasco, R.E. Wolfenden, J.L. Vicente and A.D. Wolfenden et al., 2016. Evaluation and selection of Bacillus species based on enzyme production, antimicrobial activity and biofilm synthesis as direct-fed microbial candidates for poultry. Frontiers Vet. Sci., 3: 95-95. DOI: $10.3389 /$ fvets.2016.00095

Liu, C., D.K. Baffoe, Y. Zhan, M. Zhang and Y. Li et al., 2019. Halophile, an essential platform for bioproduction. J. Microbiol. Meth., 166: 105704-105704. DOI: 10.1016/J.MIMET.2019.105704

Liu, W.Y., J. Zeng, L. Dou and S.S., Yang, 2005. Halobacillus dabanensis and Halobacillus aidingensis sp. nov., isolated from salt lakes in Xinjiang, China. Int. J. Syst. Evolut. Microbiol., 55: 1991-1996. DOI: 10.1099/ijs.0.63787-0

Makhdoumi Kakhki, A., M.A. Amoozegar and E. Mahmodi Khaledi, 2011. Diversity of hydrolytic enzymes in Haloarchaeal strains isolated from salt lake. Int. J. Environ. Sci. Technol., 8: 705-714. DOI: $10.1007 / \mathrm{BF} 03326255$.

Margesin, R. and F. Schinner, 2001. Potential of halotolerant and halophilic microorganisms for biotechnology. Extremophiles, 5: 73-83. DOI: $10.1007 / \mathrm{s} 007920100184$

Menasria, T., M. Aguilera, H. Hocine, L. Benammar and A. Ayachi et al, 2018. Diversity and bioprospecting of extremely halophilic archaea isolated from Algerian arid and semi-arid wetland ecosystems for halophilicactive hydrolytic enzymes. Microbiol. Res., 207: 289-298. DOI: 10.1016/J.MICRES.2017.12.011

Menasria, T., M. Monteoliva-Sánchez, L. Benammar, M. Benhadj and A. Ayachi et al, 2019. Culturable halophilic bacteria inhabiting Algerian saline ecosystems: A source of promising features and potentialities. World J. Microbiol. Biotechnol., 35: 132-132. DOI: 10.1007/S11274-019-2705-Y 
Mesbah, N.M. and J. Wiegel, 2012. Life under multiple extreme conditions: Diversity and physiology of the halophilik alkalithermophiles. Applied Environ. Microbiol., 78: 4047-4082.

DOI: 10.1128/AEM.00050-12.

Montalvo-Rodriguez, R., R.H. Vreeland, A. Oren, M. Kessel and C. Betancourt et al., 1998. Halogeometricum borinquense gen. nov. sp. nov., a novel halophilic archaeon from Puerto Rico. Int. J. Syst. Bacteriol., 48: 1305-1312.

DOI: 10.1099/00207713-48-4-1305

Moreno, M.D.L., M.T. Arcia, A. Ventosa and E. Mellado, 2009. Characterization of Salicola sp. IC10, a lipase and protease producing extreme halophile. FEMS Microbiol. Ecol., 68: 59-71.

DOI: 10.1111/j.1574-6941.2009.00651.x

Murray, R.G.E., R.N. Doetsch and C.F. Robinow, 1994. Determinative and Cytolocal Microscopy. In : Methods for General and Molecular Bacteriology, Gerhardt, P., R.G.E. Murray, W.A. Wood and N.R. Krieg (Eds.), ASM Press, Washington, DC, pp: 607-654.

Oren, A., 2002. Diversity of halophilic microorganisms: environments, phylogeny, physiology and applications. J. Industrial Microbiol. Biotechnol., 28: 56-63. DOI: $10.1038 / \mathrm{sj} / \mathrm{jim} / 7000176$

Oren, A., 2010. Industrial and environmental application of halophilic microorganisms. Environ. Sci. Technol., 31: 825-834. DOI: $10.1080 / 09593330903370026$

Oren, A., P. Gurevich, T.R. Gemmell and A. Teske, 1995. Halobaculum gomorrense gen. nov., sp. Nov., a novel extremely halophilic arcgaeon from the Dead Sea. Int. J. Syst. Bacteriol., 45: 747-754.

DOI: 10.1099/00207713-45-4-747

Quadri, I., I.I. Hassani, S. L'Haridon, M. Chalopin and H. Hacene et al., 2016. Characterization and antimicrobial potential of extremely halophilic archaea isolated from hypersaline environments of the Algerian Sahara. Microbiol. Res., 186-187: 119-131. DOI: 10.1016/j.micres.2016.04.003

Rajput, L., A. Imran, F. Mubeen and F.Y. Hafeez, 2013. Salt-tolerant PGPR strain Planococcus rifietoensis promotes the growth and yield of wheat (Triticum aestivum L.) cultivated in saline soil. pakistan J. Botany, 45:1955-1962.

Roberts, W.K. and C.P. Selitrennikoff, 1988. Plant and bacterial chitinases differ in antifungal activity. J. General Microbiol., 134: 169-176.

DOI: 10.1099/00221287-134-1-169

Sánchez-Porro, C., S. Martín, E. Mellado and A. Ventosa, 2003. Diversity of moderately halophilic bacteria producing extracellular hydrolytic enzymes. J. Applied Microbiol., 94: 295-300.

DOI: $10.1046 / \mathrm{j} .1365-2672.2003 .01834 . \mathrm{x}$
Setati, E.M., 2009. Diversity and industrial potential of hydrolase-producing halophilic/halotolerant eubacteria. African J. Biotechnol., 9: 1555-1560. DOI: $10.5897 / \mathrm{AJB} 10.051$

Sierra, G., 1957. A simple method for the detection of lipolytic activity of microorganisms and some observations on the influence of the contact between cells and fatty substrates. Antonie van Leeuwenhoek. J. Microbiol. Serol. Related Sci., 23: 15-22. DOI: $10.1007 / \mathrm{BF} 02545855$

Singh, P., K. Jain, C. Desai, O. Tiwari and D. Madamwar, 2019. Chapter 18 - Microbial Community Dynamics of Extremophiles/Extreme Environment. In: Microbial Diversity in the Genomic Era, Das, S., H.R. Dash and S. Dieg (Eds.), Academic Press, CA, ISBN 9780128148495. pp: 323-332.

Spring, S., W. Ludwig, M.C. Marquez, A. Ventosa and K.H. Schleifer, 1996. Halobacillus gen. nov., with descriptions of Halobacillus litoralis sp. nov. and Halobacillus trueperi sp. nov. and transfert of Sporosarcina halophila to Halobacillus halophilus comb. nov. Int. J. Syst. Evolut. Microbiol., 46: 492-496. DOI: 10.1099/00207713-46-2-492

Tamura, K., G. Stecher, D. Peterson, A. Filipski and S. Kumar, 2013. MEGA6: Molecular evolutionary genetics analysis version 6.0. Molecular Biol. Evolut., 30: 2725-2729.

DOI: $10.1093 / \mathrm{molbev} / \mathrm{mst} 197$

Teather, R.M. and P.J. Wood, 1982. Use of Congo redpolysaccharide interactions in enumeration and characterization of cellulolytic bacteria from the bovine rumen. Applied Environ. Microbiol., 43: 777-780.

Yoon, J.H., S.J. Kang, S.Y. Lee, K.H. Oh and T.K. Oh, 2010. Planococcus salinarum sp. nov., Isolated from a Marine Solar Saltern and emended description of the Genus Planococcus. Int. J. Syst. Evolut. Microbiol., 60: 754-758. DOI: 10.1099/ijs.0.013136-0

Zhao, Z., Q. Wang, K. Wang, K. Brian and C. Liu et al., 2010. Study of the antifungal activity of Bacillus vallismortis ZZ185 in vitro and identification of its antifungal components. Bioresource Technol., 101: 292-297. DOI: 10.1016/j.biortech.2009.07.071 